\title{
Effects of Fusarium spp. on Germination and Stem Rot of Sugarcane in Puerto Rico
}

\author{
Lii-Jang Liu and Julia Mignucci ${ }^{1}$
}

INTRODUCTION

Fusarium spp. were reported first in Puerto Rico by Johnston and Stevenson in $1917(6)^{2}$ on sugarcane trash, material in damp chambers, cultures of cane soil and in one instance as the apparent cause of a red rot of cane stalks. In 1920 Edgerton and Moreland (5), working with a white strain of Fusarium in Louisiana, got consistent reductions in the germination of cuttings from both top and bottom halves of stalks of the sugarcane variety D. 74. In 193;) Abbott (1) found that a purple strain of Fusarium reduced the germination of P.O.J. 213 in Louisiana as much as 41 percent below that of the control. While studying a Fusarium disease in the form of a top rot on the North Coast of Javi, Van Dillewijn (4) found in 1948 that a 30percent stalk mortality of P.O.J. 2878 occurred in October, the last month of the dry monsoon. In 1953, Bourne (3) reported that Fusarium stem rot caused major economic losses during 1951 in the Florida Everglades, with an estimated damage of 15 to 20 percent in some fields of F. 31-436. In Puerto Rico, internodal discoloration or top rot presumably caused by Fusarium moniliforme Sheldon were frequently observed in the fields, especially with the variety P.O.J. 287S. Although Tucker (7) reported the presence in Puerto Rico of the Pokkah Boeng disease of sugarcane, caused by $F$. moniliforme, he did not study the effect of this fungus on seedpiece germination and stem rot of sugarcane.

Because $F$. moniliforme is known to caluse reduction in germination of setts in Louisiana and elsewhere (5) and that uniform, good germination is essential for good crops, studies were undertaken to determine whether these isolates of Fusarium have contributed to the poor germination and depressed growth of cane under local conditions.

This paper presents data on the pathogenicity of two Fusarium isolates on sugarcane, as well as on the morphology and physiology of the isolates. The effects of various fungicides on the Fusarium isolates and Fusarium

${ }^{1}$ Phytopathologist and Research Assistant, respectively, Agricultural Experiment Station, Mayagüez Campus, Lniversity of Puerto Rico, Rio Piedras, P.R. Special thanks are due 1)r. Julio Bird, Director, Department of Phytopathology and Botany of this Station, for advice and manuseript review. Thanks also are due J)r. William suyder for identifying the species of Fusarium. This project was partially supported by a grant from ARS, USI)A (Cooperative agreement No. 12-14-100-9396 (34.)

2 Italic numbers in parentheses refer to Literature Cited, p. 434. 
seedpiece rot of sugarcane, including that of the systemic fungicide Benlate, ${ }^{3}$ also are discussed.

\section{PROCEDURE AND RESULTS}

\section{FUNGUS MORPHOLOGY, PHYSIOLOGY AND IDENTIFICATION}

Diseased seedpieces of sugarcane showing depressed growth were collected in June $196 \mathrm{~S}$ from fields at Central Monserrate and Cambalache in the north and Central Fajardo and Roig in the eastern part of the Island. Fusarium spp. were isolated from the affected canes. The fungi were isolated by planting discolored root fragments on potato dextrose agar containing pentachloronitrobenzene (PCNB) and streptomycin sultate. Subcultures of the isolates were grown in potato dextrose agar (PDA). The morphology of the fungi was studied by microscopic observation of cultures grown on PDA. Five days after inoculation, both purple and pinkish colonies appeared on the medium. Monoconidial isolations were made. An examination of the conidia produced by the monoconidial colonies revealed that all were typical of the genus Fusarium. The macroconidia produced from the purple colonies were 20.5 to $36.9 \mu$ long $\times 4$ to $5 \mu$ wide, and the microconidia 8.2 to $16.4 \mu \operatorname{long} \times 4$ to $\bar{j} \mu$ wide. Macroconidia produced from the pinkish colonies were 24.6 to $53.3 \mu$ long $\times 4$ to $5 \mu$ wide (fig. 1). The isolates were sent for identification of species to Dr. William C. Snyder, University of California, Berkeley, California. He identified the purple isolates as $F$. moniliforme and the pinkish as $F$. roseum.

Monoconidial isolates $F$. moniliforme and $F$. roseum were grown in potato dextrose agar and cornmeal agar at $8^{\circ}, 12^{\circ}, 16^{\circ}, 20^{\circ}, 24^{\circ}, 28^{\circ}, 32^{\circ}$, and $39^{\circ} \mathrm{C}$. For each temperature, five petri dishes containing $15 \mathrm{ml}$. of the above-mentioned medium were inoculated with a $2 \mathrm{~mm}$. culture disc. The dises were eut with a sterile cork borer from the advancing margin of colonies kept in cornmeal agar. The discs were incubated at the different temperatures for $\bar{i}$ days. The increment in the diameter of colonies was measured at the end of 2-day, 3-day, 4-day, and 5-day incubation periods.

The results show (table 1) that the optimum temperature range for mycelial growth of $F$. moniliforme lies between $24^{\circ}$ and $28^{\circ} \mathrm{C}$. on the two media used. The optimum temperature range for $F$. roseum, however, lies between $28^{\circ}$ and $32^{\circ} \mathrm{C}$. on the same media.

\section{PATHOGENICITY TRIALS}

\section{Infection by Dipping}

loorty seedpieces of sugar(ane variety P'O.J. 287S were dipped separately for 6 hours in spore suspensions of $F$. moniliforme and $F$. roseum, then

${ }^{3}$ Benlate benomyl (methyl 1-butylearbanoyl) 2-benzimidazole-carbamate. 
planted in metal flats containing steam-sterilized soils. Seedpieces soaked in tap-water for the same time period were used as controls. The inoculum was prepared by transferring the monoconidial isolates to Czapek Dox Broth and by blending the broth 2 weeks after incubating at $28^{\circ} \mathrm{C}$. The density of the conidia was estimated at approximately 1,000 per $\mathrm{ml}$.

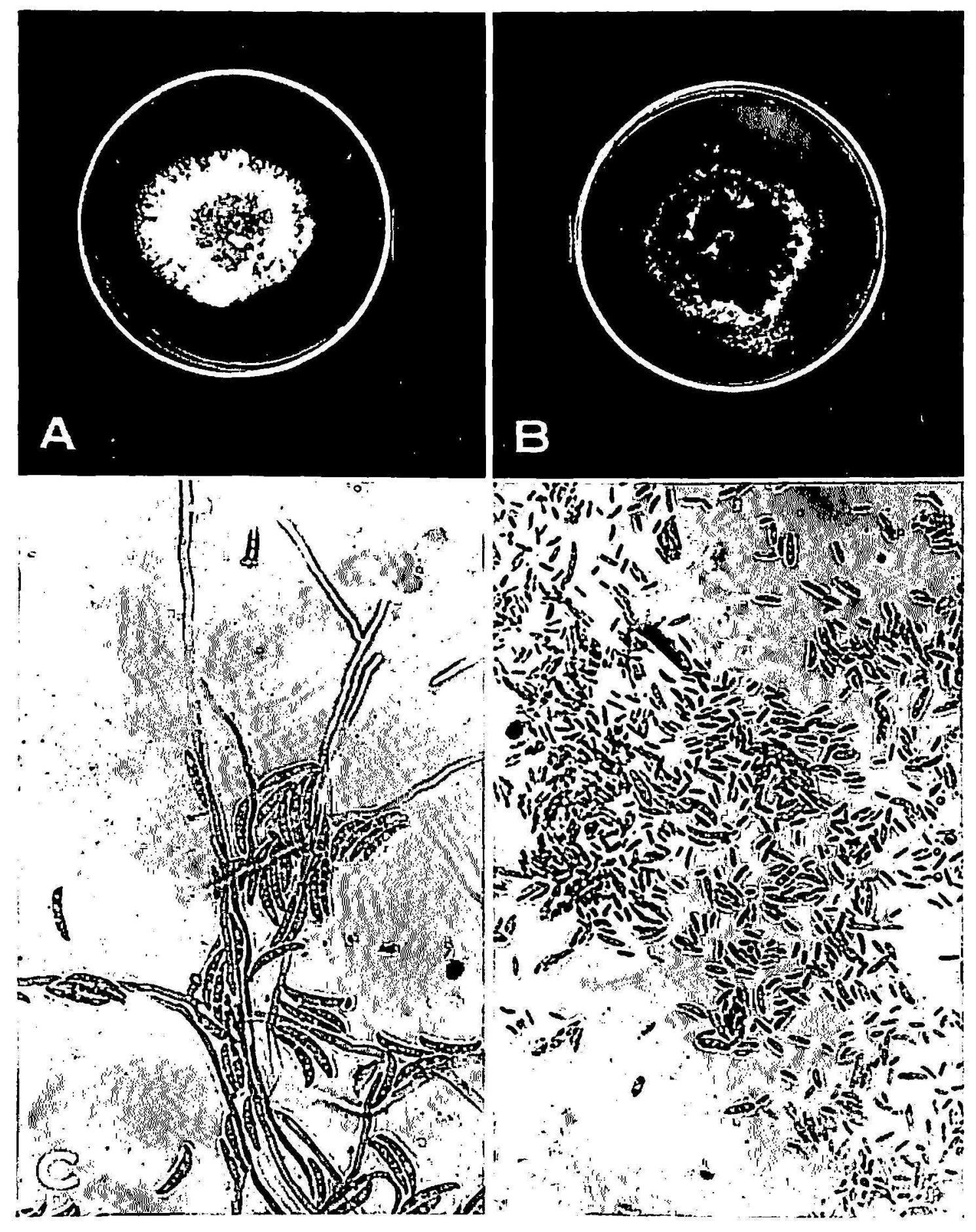

Fiti. 1. Cultural appearanee and romidia of fuserium spp.: A, Cultural appearance of $F$. roseum and B, $F$. momiliforme; $($, coniclia of $F$. rese'um; 1$)$, condidia of $F$. moniliforme. 
Six weeks after inoculation by dipping, seedpiece germinations were recorded. The results obtained indicated that $F$. moniliforme reduced the germination of P.O.J. 2878, 40 percent below that of the control. Additional tests were made with P.R. 1059, P.O.J. 2S7S, P.R. 980, P.R. 1117, N: Co. 310 and P.R. 1085 using the same inoculation method as described for the first test. The results obtained indicated that $F$. moniliforme reduced

TABLE 1.-Effect of various lemperalures, ranging from $8^{\circ}$ to $39^{\circ} \mathrm{C}$. , on increment (expressed in mm.) of diameler of colonies of Fusarium moniliforme and

F. roseum from sugarcane

\begin{tabular}{|c|c|c|c|c|c|c|c|c|c|}
\hline \multirow{2}{*}{ Fungus } & \multirow{2}{*}{$\begin{array}{c}\text { Cultural } \\
\text { media }\end{array}$} & \multirow{2}{*}{$\begin{array}{c}\text { Days } \\
\text { after } \\
\text { inocu- } \\
\text { lation }\end{array}$} & \multicolumn{7}{|c|}{ Temperature in centigrades } \\
\hline & & & $8^{\circ}$ & $16^{\circ}$ & $20^{\circ}$ & $24^{\circ}$ & $28^{\circ}$ & $32^{\circ}$ & $39^{\circ}$ \\
\hline \multirow{8}{*}{$\begin{array}{l}F . \text { monili- } \\
\text { forme }\end{array}$} & \multirow[t]{4}{*}{$\mathrm{CMA}^{1}$} & 2 & $4.0^{2}$ & 4.4 & 6.4 & 8.1 & 9.1 & 9.8 & 7.2 \\
\hline & & 3 & 4.0 & 7.5 & 14.6 & 19.4 & 23.7 & 22.9 & 7.3 \\
\hline & & 4 & 4.0 & 13.9 & 25.4 & 32.5 & 39.8 & 35.5 & 7.3 \\
\hline & & 5 & 4.0 & 32.2 & 56.9 & 72.2 & 81.0 & 63.2 & 7.3 \\
\hline & \multirow[t]{4}{*}{$\mathbf{P D A}^{3}$} & 2 & 4.0 & 4.2 & 6.2 & 9.6 & 11.0 & 12.1 & 4.0 \\
\hline & & 3 & 4.0 & 7.3 & 17.5 & 22.0 & 25.0 & 23.4 & 5.5 \\
\hline & & 4 & 4.0 & 15.6 & 28.2 & 36.5 & 41.0 & 35.5 & 5.5 \\
\hline & & 5 & 4.0 & 36.9 & 61.4 & 78.9 & 88.9 & 59.9 & 5.5 \\
\hline \multirow[t]{8}{*}{$F$, roscum } & \multirow[t]{4}{*}{ CMA } & 2 & 4.0 & 4.0 & 4.9 & 6.6 & 8.2 & 10.0 & 4.0 \\
\hline & & 3 & 4.0 & 4.7 & 11.2 & 15.0 & 19.8 & 22.9 & 4.0 \\
\hline & & 4 & 4.0 & 6.6 & 18.5 & 25.5 & 33.2 & 35.3 & 4.0 \\
\hline & & 5 & 4.0 & 14.8 & 41.2 & 57.5 & 68.8 & 75.0 & 4.0 \\
\hline & \multirow[t]{4}{*}{ PDA } & 2 & 4.0 & 4.0 & 4.5 & 7.2 & 8.1 & 10.8 & 4.0 \\
\hline & & 3 & 4.0 & 4.7 & 11.0 & 17.4 & 19.3 & 25.8 & 4.5 \\
\hline & & 4 & 4.0 & 7.7 & 18.8 & 27.7 & 34.6 & 40.0 & 5.5 \\
\hline & & 4 & 4.0 & 14.9 & 42.3 & 60.4 & 74.3 & 79.8 & 7.8 \\
\hline
\end{tabular}

1 CMA-corn meal agar.

2 Average of five replications.

${ }^{3}$ PDA-potato dextrose agar.

germination of all varieties tested, while $F$. roseum had little or no effect on germination (table 2).

\section{Infection by Substrate Inoculation}

lorty seedpieces of each variety were planted per flat in steam-sterilized soils. The canes were cut back 3 months after planting. The cut surfaces of the canes were inoculated and the soils were infected immediately with spore suspensions of $F$. moniliforme and $F$. roseum, separately. Canes inoculated with tapwater were used as controls. Four weeks after inoculation, seedpiece germination was recorded. The results indicated that inoculation with $F$. moniliforme greatly reduced stubble germination of all 
varieties tested, while inoculation with $F$. roseum had no effect on stubble germination (table 2).

\section{Infection by Stem Inoculation}

Thirty stalks each of sugarcane varieties P.R. 9S0, P.R. 10:5, P.R. 1085, P.R. 1117, N: Co. 310 and P.O.J. 2878 were inoculated with spore suspensions of $F$. moniliforme using the stem-puncture technique. The inoculum was increased in Czapek Dox Broth. Seven days after inoculation, the inoculated stalks were split with a knife for examination. As indicated by the lengths of the internal lesions in the stalls (table 3), the results cbtained show that P.R. 980 was the most resistant variety to F. momili-

TaвL: 2.-Effect of Fusarium spp. on germination of sugarcane

\begin{tabular}{|c|c|c|c|c|c|c|}
\hline \multicolumn{4}{|c|}{ Percent germination of plant cane } & \multicolumn{3}{|c|}{ Percent germination of stubble' } \\
\hline Variety & Control & $F \cdot \begin{array}{c}\text { monili- } \\
\text { forme }\end{array}$ & $\begin{array}{c}\text { F. } \\
\text { roscim }\end{array}$ & Control & $\underset{\text { forme }}{F}$ & $\underset{\text { roseums }}{F .}$ \\
\hline P.R. 980 & $73^{2}$ & 40 & 53 & 100 & 52 & 91 \\
\hline P.R. 1059 & 13 & 3 & 10 & 62 & 30 & 82 \\
\hline P.R. 1085 & 60 & $2 \bar{T}$ & (i0 & 90 & 79 & 91 \\
\hline P.R. 1117 & 57 & 33 & 40 & 85 & 10 & bij \\
\hline P.O.J. 2878 & 50 & 17 & 53 & 92 & 70 & 90 \\
\hline $\mathrm{N}:$ Co. 310 & 30 & 6 & 30 & 95 & 59 & 91 \\
\hline
\end{tabular}

1 Canes were cut back at 3 months of age.

2 Average of five replications.

forme, and that P.R. 1085, P.O.J. 2878 and P.R. 1059 were comparatively most susceptible (fig. 2).

\section{CHEMICAL CONTROL,}

Four chemicals, Benlate, Busan 72,4 Daconil, ${ }^{5}$ and Dithane M $\left(-45^{6}{ }^{6}\right.$ were tested in the laboratory at $0.5-, 1.0$ - and 1.j-percent concentrations for their toxicity against $F$. momiliforme. $F$. moniliforme was grown on potato dextrose agar medium, to which four $2-\mathrm{mm}$. paper discs containing varying concentrations of technical grade Benlate, Busan 72, Daronil and Dithane M-45 were added. Paper dises containing no fungicides were added to the plates used as controls. As shown in figure 3, Busan 72 and Benlate appeared to be most effective fungicides for inhibiting mycelial growth of $F$. moniliforme.

4 Busan 72-80 percent of 2-(thiocyanomethylthio) benzothiazole.

5 Daconil 2787-tetrachloro isophthalonitrile.

- Dithane M-45 coordination product of zine ion and manganese ethylene bisdithiocarbamate. 
Benlate and Busan 72 also were studied under greenhouse conditions. Steam-sterilized soils, infected with a spore suspension of $F$. moniliforme, were used. Seedpieces of sugarcane variety P.O.J. 2878 were dipped in

T.вLL; 3.-Effecl of Fusarium spp. on slem rol of sugarcane

\begin{tabular}{lcc}
\hline \multirow{2}{*}{ Vatiety } & \multicolumn{2}{c}{ Length of internal lesion } \\
\cline { 2 - 3 } & Fusarium monsiliforme & F. roseum \\
\hline P.R. 980 & Inches & Inches \\
P.R. 1059 & $1.92^{1}$ & 1.62 \\
P.R. 1085 & 2.15 & 2.03 \\
P.R. 1117 & 3.11 & 2.21 \\
N. Co. 310 & 2.31 & 2.00 \\
P.O.J. 2878 & 2.09 & 1.89 \\
& 2.01 & 1.37 \\
\hline
\end{tabular}

${ }^{1}$ Average of 28 to 30 stalks.

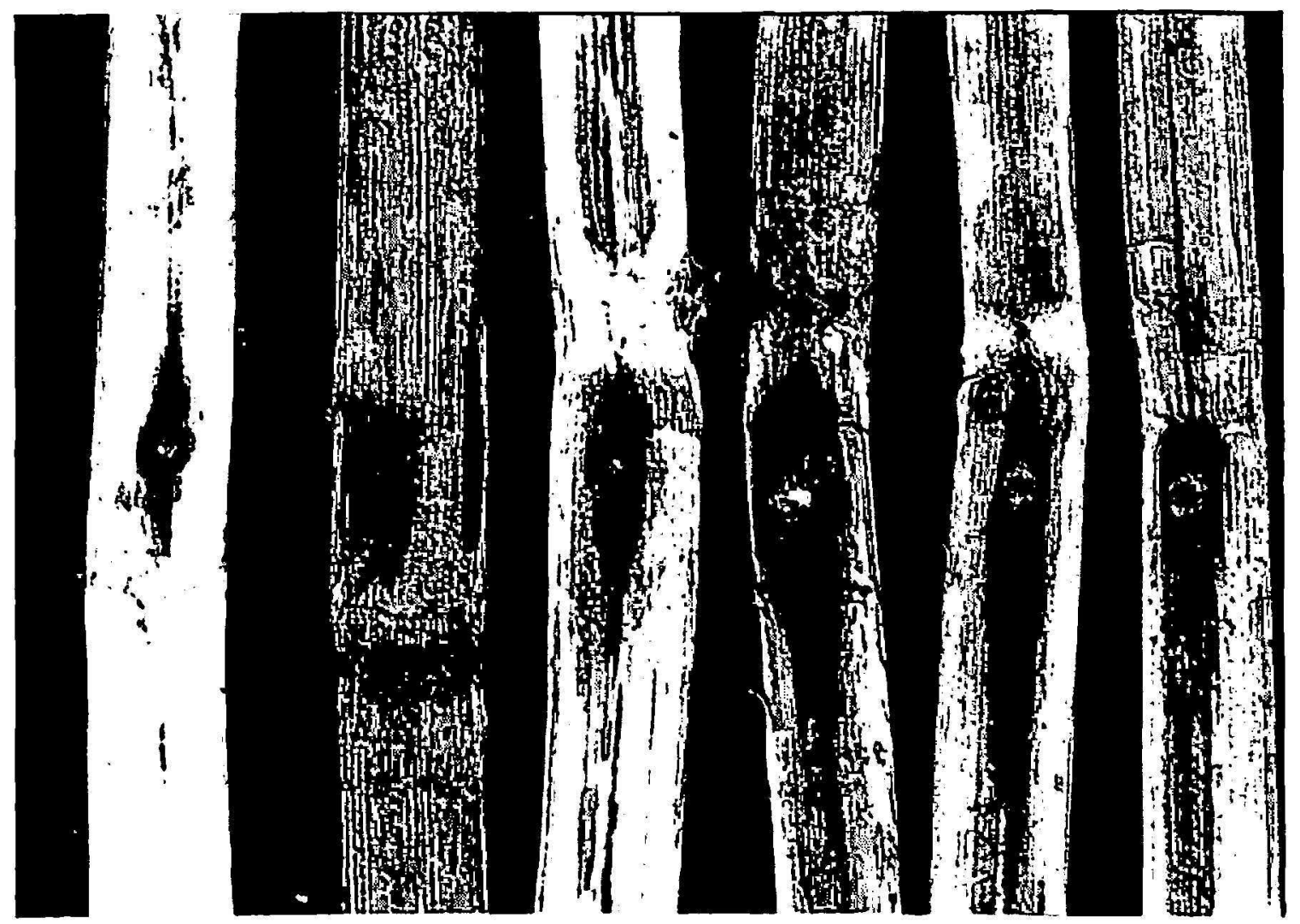

Fig. 2. Sugarcane stalks inoculated with spore suspension of Fusarium momiliforme via stem-puncture technique (from left to right P.R. 980 P.O.J. 2878, N: Co. 3.10, P.R. 1059, P.R. 1117, and P.R. 1085.

varying concentrations of Benlate and Busan 72 before planting. Seedpieces dipped in sterile water before planting were used as controls. Germination of P.O.J. 2878 was greatly improved when seedpieces were dipped in in- 
creased concentrations of both Benlate and Busan 72, with 80 percent and 70 percent germination respectively (table 4 ).

A field trial with Benlate was established at the Isabela Substation. The

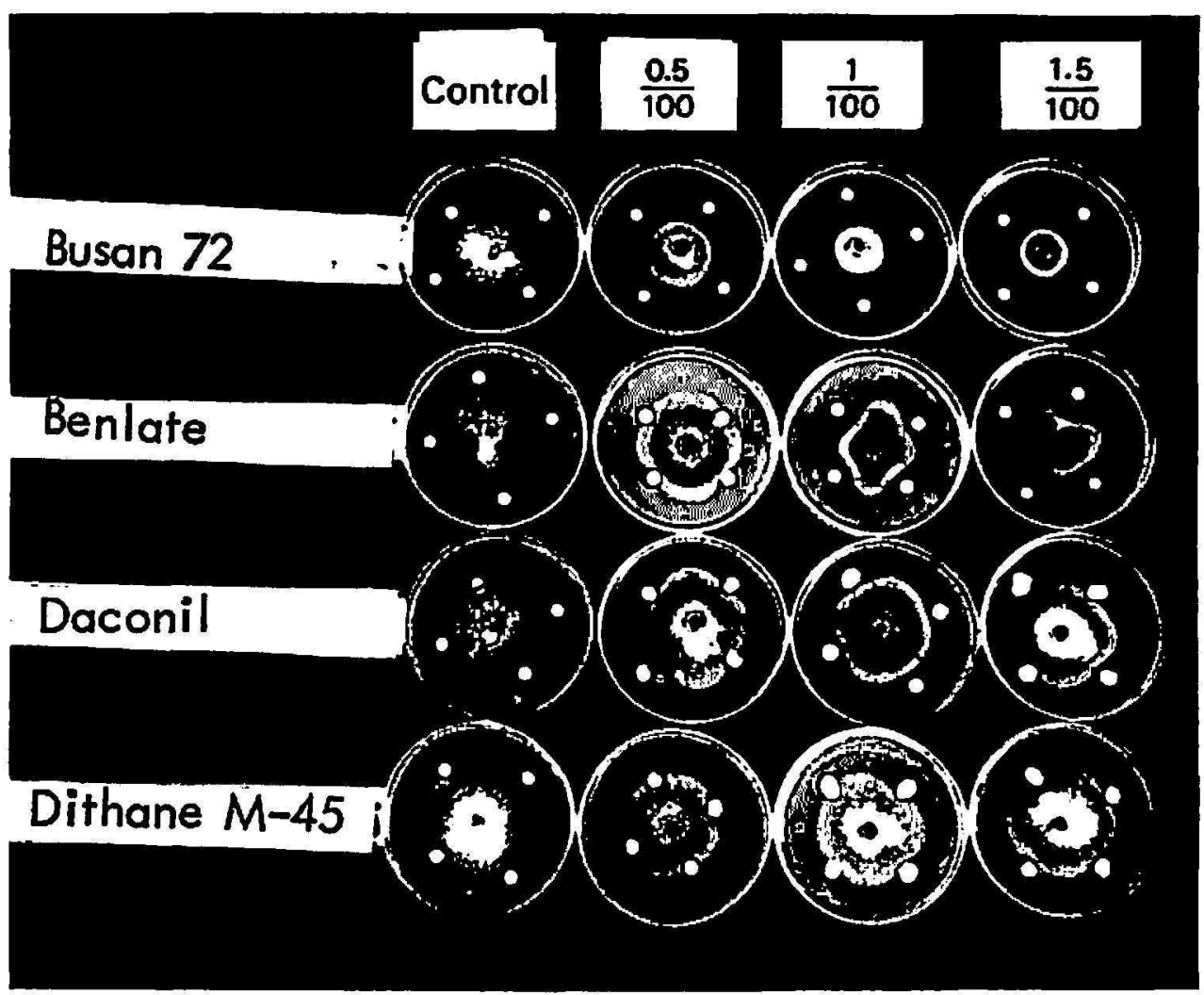

Fus. 3.- Elfect of varions concentrations of fungicices: Busau 72, Benlate, Daconil and Dithane M-45 un mycelial growth of Fusarium moniliforme.

T.ABLE: 4.-Efeet of various fungicides on secdpiere germination of sugarcane variety P.O.J. 2878 planted in Fusurium moniliforme-infecled soils under greenhouse conditions

\begin{tabular}{ccc}
\hline Chemical & Concentration & Germination \\
\hline \multirow{3}{*}{ Benlate } & Percent & Percent \\
& 0.5 & $65^{1}$ \\
Busant 72 & 1.0 & 65 \\
& 1.5 & 80 \\
& 1.0 & 40 \\
Control & 2.0 & 55 \\
& 3.0 & 70 \\
\end{tabular}

1 Average of threc replications.

following four treatments were used: Seedpieces of P.R. 9S0 were dippred before planting in: 1 , tap water (control); 2 , a spore suspension of $F$. moniliforme; 3, a 1.0-percent solution of Benlate; 4, a 1-percent solution of Benlate 
but inoculated the night before with a spore suspension of $F$. moniliforme. A complete randomized block design with three replications was used for this trial.

As shown in table 5, seedpieces inoculated with $F$. moniliforme had a poorer germination than healthy ones, but their germination was better when treated with a 1-percent solution of Benlate.

\section{DISCUSSION}

The results obtained in these studies indicate that $F$. moniliforme affects seedpiece and stubble germination of sugarcane. These results agree with the findings of Edgerton and Moreland (5) and Abbott (1) in Louisiana. This is the first report on the incidence and effects of Fusarium spp. on germination of sugarcane in Puerto Rico.

T.ıн1: 5.-Effert of Benlale on seedpiece germination of sugarcane variety P.R. 980 infected wilh Fusarium moniliforme under field conditions

\begin{tabular}{llc}
\hline Treatment & $\begin{array}{c}\text { Percent } \\
\text { Germi- } \\
\text { nation }\end{array}$ \\
\hline O & Seedpieces dipped in tap water & $71^{1}$ \\
B & Seedpieces dipped in 1-percent solution of Benlate & 65 \\
FB & Seedpiece dipped in 1-percent Benlate but inoculated with spore \\
& suspension of $F$. moniliforme the night before planting \\
$F^{2}$ & Seedpieces dipped in a spore suspension of $F$. moniliforme the & 25 \\
& night before planting & \\
\hline
\end{tabular}

1 Average of three replications.

${ }^{2}$ Without dipping in 1-pereent solution of Benlate.

The results obtained under greenhouse conditions also indicate that both $F$. moniliforme and $F$. roseum are cupable of causing stem rot of sugarcane when conditions are favorable.

Although Bartels and MacNeill (2) reported that several mutants of Fusarium were resistant to Benlate, results obtained in these studies indicate that Benlate not only inhibits mycelial growth of $F$. moniliforme in vitro but also protects seedpieces of sugarcane against the fungus under both greenhouse and field conditions.

\section{SUMMARY}

Fusarium moniliforme and $F$. roseum were isolated from the diseased seedpieces of sugarcane plants. Various methods were employed to inoculate canes with the different isolates, i.e., seedpiece-dipping, addition of inoculum to the substrate, and stem-puncture. $F$. moniliforme reduced germination of variety P.O.J. 2878 as much as 40 percent when seedpiecedipping and substrate infection methods were used. Inoculation with 
F. roseum had little effect. Sugarcane varieties P.O.J. 2878, P.R. 1117, P.R. 980, P.R. 1059, P.R. 1085 and $N$ : Co. 310 proved susceptible in varying degrees when inoculated with $F$. moniliforme by the stem-puncture method. Among the chemicals tested, Benlate, a systemic fungicide, seemed to be most promising for protecting sugarcane seedpieces against Fusarium rot.

\section{IRESUMEN}

De pedazos del tallo de caña de azúcar enferma, usados para semilla, se aislaron el Fusarium moniliforme y $F$. roseum. Se usaron varios métodos para inocular caña sana con los organismos aislados, a saber, el de inmersión de la semilla, infección por inoculación del substrato y punzadura del tallo. Cuando se usaron los métodos de inmersión de la semilla e inoculación del substrato, el $F$. moniliforme redujo la germinación de la variedad P.O.J. 2878 hasta en un 40 por ciento. La inoculación con el $F$. roseum surtí poco efecto. Las variedades P.O.J. 2878, P.R. 1117, P.R. 980, P.R. 1059, P.R. 1085 y Na. Co. 310 variaron en su grado de susceptibilidad, cuando se inocularon con el $F$. moniliforme punzando el tallo. Entre los agentes químicos que se probaron, el fungicida sistémico Benlate pareció ser el más prometedor para proteger los pedazos de caña para semilla contra la podredumbre causada por el Fusarium.

\section{LITEIRATURE CITED}

1. Abbott, E. V., Economic importance of red rot and comparative susceptibility of some sugarcane varieties in the southern United States, USI)A Cir. 350, 1-26, illus., 1935.

2. Bartels, J., and MacNeill, B. H., The response of several mutants of Fusarium to benomyl and related fungicides, Phylopathology 60:571, 1970 (Abstr.).

3. Bourne, B. A., Studies on sugarcane red rot in the Florida Everglades, Inler. Soc. Sugarcane Technol. Proc. 8: 915-24, 1953.

4. Dillewijn, C. Van, Stalk population, yield composition and Fusarium top rot in sugareane, Sugar 48 (1): 28-30, 1948.

5. Edgerton, C. W. and Moreland, C. C., Effect of fungi on the germination of sugarcane, La. Agr. Exp. Sta., Bull. 169, 1-40, illus., 1920.

6. Johnston, J. R. and Stevenson, J. A., Sugareane fungi and disense of Puerto Rico, The J. Dept. Agr. P.R. 1 (4): 177-251, 1917.

7. Tucker, C. M., Pokkah boeng disease of sugarcane, Rpt. Puerto Rico Agr. Exp. Sta., 33-5, 1929. 